\title{
Introduction to Stem Cells and Regenerative Medicine
}

\author{
George Kolios $^{\text {a }}$ Yuben Moodley ${ }^{b-d}$ \\ aLaboratory of Pharmacology, Faculty of Medicine, Democritus University of Thrace, Alexandroupolis, Greece; \\ ${ }^{\mathrm{b}} \mathrm{S}$ chool of Medicine and Pharmacology, University of Western Australia, and ' Department of Respiratory and \\ Sleep Medicine, Royal Perth Hospital, and ${ }^{d}$ Lung Institute of Western Australia, Perth, W.A., Australia
}

\section{Key Words}

Tissue-resident stem cells • Induced pluripotent stem cells • Mesenchymal stem cells

\begin{abstract}
Stem cells are a population of undifferentiated cells characterized by the ability to extensively proliferate (self-renewal), usually arise from a single cell (clonal), and differentiate into different types of cells and tissue (potent). There are several sources of stem cells with varying potencies. Pluripotent cells are embryonic stem cells derived from the inner cell mass of the embryo and induced pluripotent cells are formed following reprogramming of somatic cells. Pluripotent cells can differentiate into tissue from all 3 germ layers (endoderm, mesoderm, and ectoderm). Multipotent stem cells may differentiate into tissue derived from a single germ layer such as mesenchymal stem cells which form adipose tissue, bone, and cartilage. Tissue-resident stem cells are oligopotent since they can form terminally differentiated cells of a specific tissue. Stem cells can be used in cellular therapy to replace damaged cells or to regenerate organs. In addition, stem cells have expanded our understanding of development as well as the pathogenesis of disease. Disease-specific cell lines can also be propagated and used in drug
\end{abstract}

development. Despite the significant advances in stem cell biology, issues such as ethical controversies with embryonic stem cells, tumor formation, and rejection limit their utility. However, many of these limitations are being bypassed and this could lead to major advances in the management of disease. This review is an introduction to the world of stem cells and discusses their definition, origin, and classification, as well as applications of these cells in regenerative medicine.

Copyright $\odot 2012$ S. Karger AG, Basel

\section{Introduction}

Stem cells are undifferentiated cells that are present in the embryonic, fetal, and adult stages of life and give rise to differentiated cells that are building blocks of tissue and organs. In the post-natal and adult stages of life, tissue-specific stem cells are found in differentiated organs and are instrumental in repair following injury to the organ. The major characteristics of stem cells are: (a) self-renewal (the ability to extensively proliferate), (b) clonality (usually arising from a single cell), and (c) potency (the ability to differentiate into different cell types). These properties may differ between various stem cells. For example, embryonic stem cells (ESCs)

\section{KARGER}

Fax +4161306 1234

E-Mail karger@karger.ch

www.karger.com
(C) 2012 S. Karger AG, Basel

0025-7931/13/0851-0003\$38.00/0

Accessible online at:

www.karger.com/res
Prof. George Kolios, MD, PhD

Laboratory of Pharmacology

Faculty of Medicine, Democritus University of Thrace

Dragana, GR-68100 Alexandroupolis (Greece)

E-Mail gkolios@med.duth.gr 
Fig. 1. The hierarchy of stem cells. Totipotent cells form embryonic and extra-embryonic tissue. Pluripotent cells form all 3 germ layers while multipotent cells generate cells limited to 1 germ layer. Bronchoalveolar duct junction cells in the lung may be multipotent while type II pneumocytes are oligopotent and differentiate into type I pneumocytes of the alveoli.

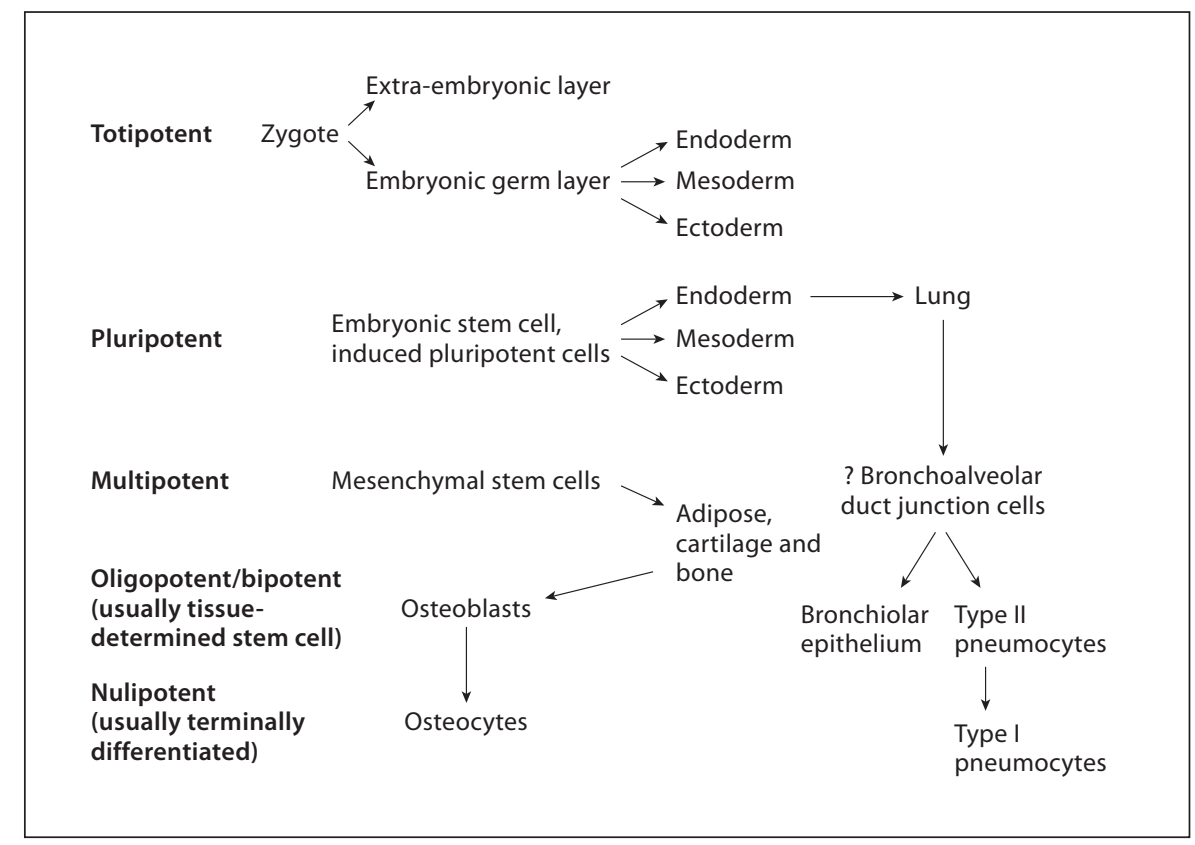

derived from the blastocyst have a greater ability for self-renewal and potency while stem cells found in adult tissue have limited self-renewal since they would not proliferate extensively and can only differentiate into tissue-specific cells.

The human body develops from the zygote and blastocyst from which ESCs are derived into the germ layers endoderm, mesoderm, and ectoderm. Specific organs arise from the germ layers. Some of the progenitor cells that have contributed to organ formation do not terminally differentiate but are retained as tissue stem cells and can be found in bone marrow, bone, blood, muscle, liver, brain, adipose tissue, skin, and the gastrointestinal tract $[1,2]$. The tissue stem cells may be called progenitor cells since they give rise to terminally differentiated and specialized cells of the tissue or organ. These cells may be dormant within tissue but would proliferate under circumstances of injury and repair [3-5]. The dynamics of tissue stem cells or progenitor cells varies from tissue to tissue; for example, in bone marrow, liver, lung, and gut, stem cells regularly proliferate to supplement cells during normal turnover or injury [6-9], while in the pancreas, the heart, or the nervous system they proliferate to replace damaged cells following injury [10-14].

The idea of wound repair and organ regeneration is as old as humanity and is reflected in the ancient Greek myth of Prometheus, the Greek titan punished by Zeus for his disobedience in introducing fire and knowledge to human beings. In this myth, Prometheus is tied to a rock and everyday an eagle eats part of his liver which then regenerates. In modern-day medicine, work involving stem cells and organ regeneration commenced with the first attempts at bone marrow transplantation in animal models during the 1950s. These pioneering studies paved the way for human bone marrow transplantation [15], a therapy now widely used in various blood disorders [16]. This new therapeutic strategy revealed the existence of stem cells that regenerated adult tissue [17]. Presently, regenerative medicine is a major focus of research not only to find therapies but also to understand basic biology and the pathogenesis of disease [18-20]. Although a number of ethical issues have arisen in stem cell research [21], recent advances in stem cell isolation and development have helped scientists to identify and culture specific cell types for regeneration of tissue in various disorders such as Parkinson's [22], Alzheimer's [23], or diseases of the heart [24], muscles [25], lung [26, 27], liver [28], and other organs [14].

\section{Stem Cell Classification Based on Differentiation Potential}

The ability to differentiate, one of the two main characteristics of stem cells, varies between stem cells depending on their origin and their derivation (fig. 1). All 
Table 1. Stem cell classification according to their differentiation potential and origin

\begin{tabular}{ll}
\hline Differentiation potential & Origin \\
\hline $\begin{array}{l}\text { Totipotent or omnipotent } \\
\text { Pluripotent }\end{array}$ & \\
Multipotent & ESCs, iPSCs \\
Oligopotent & Fetal stem cells \\
Unipotent & Adult or somatic stem cells \\
\hline
\end{tabular}

stem cells can be categorized according to their differentiation potential into 5 groups: totipotent or omnipotent, pluripotent, multipotent, oligopotent, and unipotent (table 1) [29].

\section{Totipotent Cells}

Totipotent or omnipotent cells are the most undifferentiated cells and are found in early development. A fertilized oocyte and the cells of the first two divisions are totipotent cells, as they differentiate into both embryonic and extraembryonic tissues, thereby forming the embryo and the placenta [30].

\section{Pluripotent Cells}

Pluripotent stem cells are able to differentiate into cells that arise from the 3 germ layers - ectoderm, endoderm, and mesoderm - from which all tissues and organs develop [31]. Pluripotent stem cells called ESCs were first derived from the inner cell mass of the blastocyst [32]. Recently, Takahashi and Yamanaka [33] generated pluripotent cells by reprogramming somatic cells. These cells are called induced pluripotent stem cells (iPSCs) and share similar characteristics with ESCs. Notably, there has been no pluripotent cell population isolated from the lung.

\section{Multipotent Cells}

Multipotent stem cells are found in most tissues and differentiate into cells from a single germ layer [34]. Mesenchymal stem cells (MSCs) are the most recognized multipotent cell. They can be derived from a variety of tissue including bone marrow, adipose tissue, bone, Wharton's jelly, umbilical cord blood, and peripheral blood [35]. MSCs are adherent to cell culture dishes and are characterized by specific surface cell markers. These cells can differentiate into mesoderm-derived tissue such as adipose tissue, bone, cartilage, and muscle [35-38]. Recently, MSCs were differentiated into neuronal tissue which is derived from the ectoderm. This is an example of transdifferentiation, i.e. when a cell from one germ layer (mesoderm) differentiates into neuronal tissue (ectoderm) [39]. Tissue-resident MSCs have been isolated from the lung; however, no other multipotent cell has been isolated to date [40].

\section{Oligopotent Cells}

Oligopotent stem cells are able to self-renew and form 2 or more lineages within a specific tissue; for example, the ocular surface of the pig, including the cornea, has been reported to contain oligopotent stem cells that generate individual colonies of corneal and conjunctival cells [41]. Hematopoietic stem cells are a typical example of oligopotent stem cells, as they can differentiate into both myeloid and lymphoid lineages [42]. In the lung, studies suggest that bronchoalveolar duct junction cells may give rise to bronchiolar epithelium and alveolar epithelium [43].

\section{Unipotent Cells}

Unipotent stem cells can self-renew and differentiate into only one specific cell type and form a single lineage such as muscle stem cells, giving rise to mature muscle cells and not any other cells [44-47]. In the lung, type II pneumocytes of the alveoli give rise to type I pneumocytes.

\section{Stem Cell Classification Based on Origin}

Stem cells can be grouped into 4 broad categories based on their origin: ESCs, fetal and adult stem cells, and iPSCs (table 1) [48, 49]. In general, ESCs and iPSCs are pluripotent, whereas adult stem cells are oligopotent or unipotent.

\section{Embryonic Stem Cells}

ESCs are pluripotent, derived from the inner cell mass of the blastocyst, a stage of the pre-implantation embryo, 5-6 days post-fertilization [32]. These cells can differentiate into tissue of the 3 primary germ layers but can also be maintained in an undifferentiated state for a prolonged period in culture [50]. The blastocyst has 2 layers of cells, i.e. the inner cell mass, which will form the embryo, and the outer cell mass, called trophoblasts, that will form the placenta. Cells from the inner cell layer are separated from trophoblasts and transferred to a culture dish under very specific conditions to develop ESC lines [51]. ESCs are identified by the presence of transcription factors such as Nanog and Oct4 $[52,53]$. These factors maintain the stem 
cells in an undifferentiated state, capable of self-renewal $[53,54]$. ESCs that have been cultured in an undifferentiated state with no genetic abnormalities are propagated as an ESC line. These cells could be frozen and thawed for further cultures and experimentation [55]. Culture conditions are critical in maintaining ESCs in an undifferentiated state. A feeder layer of embryonic fibroblast cells (MEFCs) or medium that contains the anti-differentiation cytokine leukemia inhibitory factor (LIF) are used. Withdrawal of LIF from the medium or removal of the ESCs from the feeder layer results in the formation of 'embryoid bodies', in which all 3 germ layers (endoderm, mesoderm, and ectoderm) are present [56-60].

\section{Adult Stem Cells}

Adult stem cells are derived from adult tissue. Examples include MSCs as well as stem cells derived from placental tissue such as human amnion epithelial cells. These cells have been shown to be anti-inflammatory and augment repair of animal models of injury. They have limited differentiation capacity although these cells have been differentiated into tissue from different germ cell layers in vitro [61, 62].

Adult stem cells are of advantage since autologous cells do not raise issues of rejection or ethical controversies [21, 63]. Adult stem cells could be obtained from all tissues of the 3 germ layers as well as placenta. Several studies have demonstrated that transplantation of adult stem cells restores damaged organs in vivo, such as bone tissue repair and revascularization of the ischemic cardiac tissue via stem cell differentiation and generation of new specialized cells [64-66]. Other studies have shown that cultured adult stem cells secrete various molecular mediators with anti-apoptotic, immunomodulatory, angiogenic, and chemoattractant properties that promote repair $[67,68]$.

\section{Tissue-Resident Stem Cells}

The ability of some tissues and organs in the adult to renew and repair following injury is critically dependent on tissue-resident stem cells that generate tissue-specific, terminally differentiated cells [69]. Studies suggest that these cells originate during ontogenesis and remain in a quiescent state till local stimuli activate their proliferation, differentiation or migration [70, 71].

Tissue-resident stem cells reside in a 'stem cell niche' [72]. The stem cell niche is a microenvironment that controls the self-renewal and differentiation of these cells [73]. There is a growing body of evidence that stem cell function is critically influenced by extrinsic signals from the microenvironment; therefore, the niche plays a cru- cial role in stem cell homeostasis and tissue repair [7476]. The majority of tissue-resident stem cells are dormant but are activated by specific signals during injury and repair [73]. This dormancy of tissue-resident stem cells is not well understood but is likely influenced by the niche environment. This property is critical to maintaining a population of cells that do not perform other functions apart from generating tissue-specific cells during repair [77]. The niche environment consists of various signals from extracellular matrix and soluble mediators that mediate cell signaling and gene expression [78-81], thereby regulating stem cell proliferation, migration, differentiation, or apoptosis $[82,83]$. We still need to elucidate what the triggers are for stem cells to move from a self-renewal state and proliferation to differentiation and whether these signals are tissue specific.

Furthermore, the types of cell division that a stem cell undergoes determine the cells the type of cells generates. Symmetrical cell division by a stem cell results in identical daughter cells, which provides new cells to restitute damaged cells following injury $[84,85]$ (fig. 2). It is important to note that an uncontrolled increase in stem cell proliferation could lead to stem cell hyperplasia and/or carcinogenesis while a reduction in stem cells would impair organ repair; thus, balance in stem cell homeostasis is very important [86].

Asymmetric division occurs when a stem cell generates an identical daughter cell and a second differentiated daughter cell. This process allows for organ repair and regeneration while maintaining a population of stem cells [87-89].

\section{Induced Pluripotent Stem Cells}

iPSCs are produced from adult somatic cells that are genetically reprogrammed to an 'ESC-like state' [90]. Mouse iPSCs were reported for the first time by Takahashi and Yamanaka [33] in 2006 by transducing mouse fibroblasts with 4 genes encoding the following transcription factors: octamer-binding transcription factor 3/4 (OCT3/4), SRY-related high-mobility group box protein-2 (SOX2), the oncoprotein c-MYC, and Kruppel-like factor 4 (KLF4). A year later, in 2007, Yamanaka and collegues [91] described the generation of human iPSCs from adult human dermal fibroblasts with the same 4 factors: Oct3/4, Sox2, Klf4, and c-Myc. They demonstrated that these cells were similar to human ESCs in terms of morphology, proliferation, surface antigens, gene expression, epigenetic status of pluripotent cell-specific genes, and telomerase activity, and they could differentiate into cell types of the 3 germ layers in vitro [91]. iPSCs are cur- 


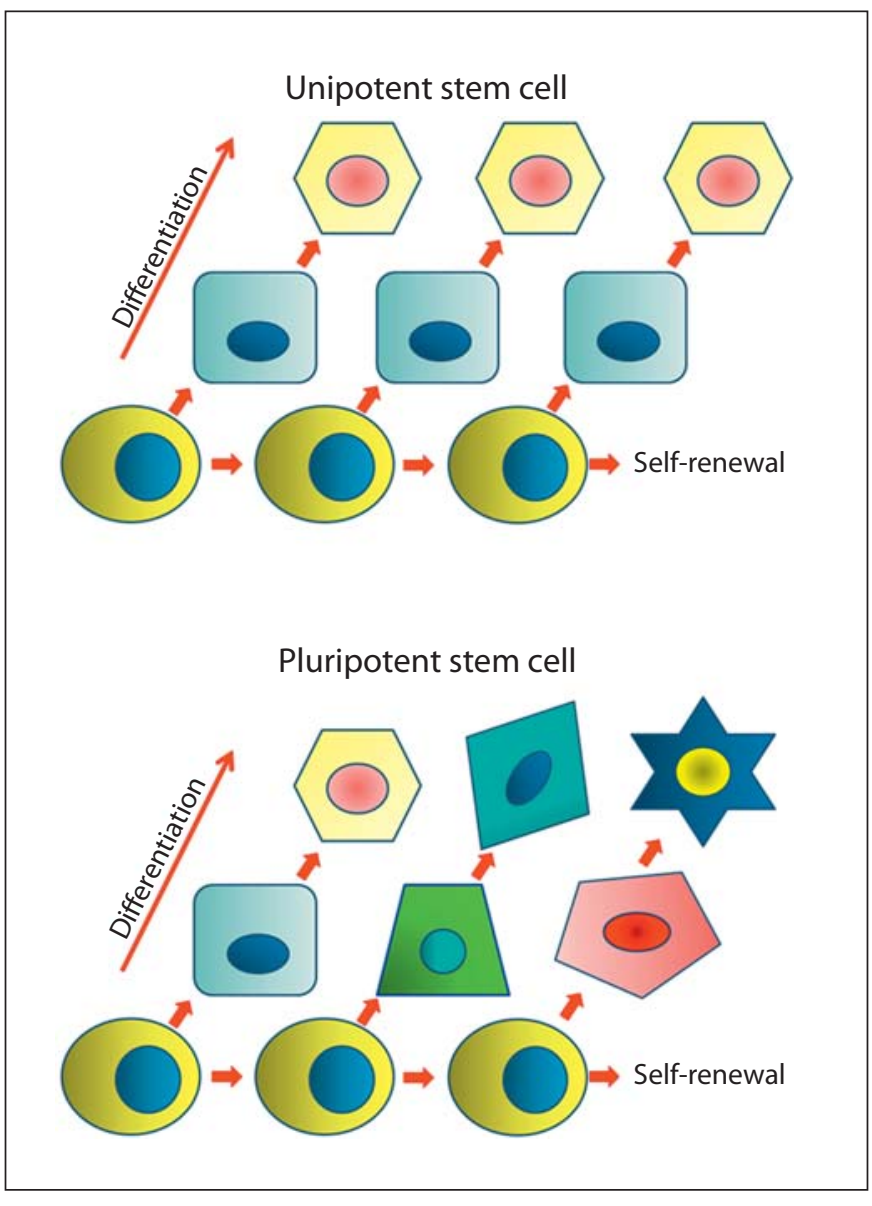

Fig. 2. Stem cells are characterized by their ability to self-renew and differentiate. Each individual daughter cell could go further in a symmetric division giving more stem cells or differentiate into one or more specialized cells, depending in the pluripotency of the stem cell, maintaining the population of tissue cells.

rently useful tools for drug development, modeling of diseases, and regenerative medicine, but although these cells express identical characteristics of pluripotent stem cells [92] it is not yet known if iPSCs and ESCs would significantly differ in clinical practice.

Retroviral vectors, used to introduce the reprogramming factors into adult cells, and oncogenes like c-Myc limit the use of iPSCs in a clinical study since the vectors used to introduce transcription factors to adult cells can cause cancers [93]. Researchers are currently investigating new methods to generate safe iPSCs without genomic manipulation [94]. New techniques have been described, using several types of mouse and human adult somatic cells. To avoid the use of oncoproteins c-MYC and KLF4 they have used one factor (OCT3/4 or KLF4) or they have substituted them with combinations of other factors [95, 96], including the use of non-retroviral vector approaches, such as chemical compounds, plasmids, adenovirus, and transposons [97-100].

Despite the safety issues, this innovative discovery has created a powerful tool to reprogram somatic adult cells 'sending them back' to earlier undifferentiated stages and generating iPSCs, thereby creating an identical match to the cell donor and thus avoiding issues of rejection.

\section{Stem Cells in Clinical Practice and Regenerative Medicine}

The contribution of stem cells in modern medicine is of paramount importance, both for their broad use in basic research and for the opportunities they give us to develop new therapeutic strategies in clinical practice [101]. Their characteristics make them valuable in a wide range of applications in biological and medical sciences [18]. For example, ESCs are excellent tools to understand human development and organogenesis. Stem cells such as iPSCs will be critical in the investigation of new and safe therapies.

In addition, stem cells may be able to replace damaged tissue or even regenerate organs [14]. iPSCs provide the opportunity to set up human models of diseases that would improve the understanding of the pathogenetic mechanisms of human diseases and would enable improvements in cell-based therapy for degenerative disorders [18].

Cell therapy has been investigated in almost every degenerative disorder. Promising results from preclinical studies and clinical trials have already been described in several diseases, such as diabetes mellitus [102, 103], chronic myeloid leukemia [104, 105], cirrhosis [106, 107], pulmonary fibrosis $[108,109]$, Crohn's disease [110, 111], heart failure $[66,112]$, and disorders of the nervous system [113-117], and the immunomodulatory effects of stem cells have found their utility in several conditions characterized by predominant inflammation $[118,119]$.

There are issues to consider in cell therapy and regenerative medicine. Immunorejection is still a consideration although MSCs and placental tissue as well as iPSCs circumvent the problem. The genetic stability of stem cells, especially iPSCs, remains to be elucidated. Genetic instability can give rise to tumor formation. Indeed the plasticity and self-renewal that characterize stem cells could lead to carcinogenesis in the host tissue [120], while spontaneously occurring teratomas and related tumors could develop from the use of ESCs or iPSCs in therapeu- 
tic cell transplantation [121]. Finally, a number of ethical concerns have been raised mainly in the use of ESCs [122]. These include the ethical controversies of destroying an embryo in generating ESCs. This can now be potentially bypassed by iPSCs.

\section{Conclusions}

Stem cells are an important tool for understanding both the organogenesis and the continuous regenerative capacity of the body. They could be a model for the study of pathogenetic mechanisms and could assist researchers in understanding the pathophysiology of various diseases. They also offer the possibility of developing biological models for the study of new pharmacological agents. However, the most important potential of these cells is to replace damaged tissue and even regenerate organs. To date, a large number of research protocols, preclinical studies, and clinical trials have been published. Although, several clinical studies have already reported encouraging results for the development of new therapeutic strategies in cell-based medicine, there are a number of risks and obstacles. Despite this, there is ongoing research and development that gives us great optimism about regenerative medicine.

\section{References}

1 Denham M, Conley B, Olsson F, Cole TJ, 15 Dameshek W: Bone marrow transplantation; Mollard R: Stem cells: an overview. Curr Protoc Cell Biol 2005;23:23.1.

$\checkmark 2$ Vats A, Bielby RC, Tolley NS, Nerem R, Polak $>16$ de la Morena MT, Gatti RA: A history of bone JM: Stem cells. Lancet 2005;366:592-602.

$>3$ Lajtha LG: Stem cells and their properties. Proc Can Cancer Conf 1967;7:31-39.

$\checkmark 4$ He S, Nakada D, Morrison SJ: Mechanisms of stem cell self-renewal. Annu Rev Cell Dev Biol 2009;25:377-406

5 Falanga V: Stem cells in tissue repair and regeneration. J Invest Dermatol 2012;132: 1538-1541.

$\checkmark 6$ Lane S, Rippon HJ, Bishop AE: Stem cells in lung repair and regeneration. Regen Med 2007;2:407-415.

7 Fausto N: Liver regeneration and repair: hepatocytes, progenitor cells, and stem cells. Hepatology 2004;39:1477-1487.

$>8$ Shaker A, Rubin DC: Stem cells: one step closer to gut repair. Nature 2012;485:181-182.

9 Han W, Yu Y, Liu XY: Local signals in stem cell-based bone marrow regeneration. Cell Res 2006;16:189-195.

10 Angelini A, Castellani C, Vescovo G, Thiene G: Pathological evidence of stem cell regeneration in the heart. Int J Cardiol 2004;96: 499-504.

- 11 Mirotsou M, Jayawardena TM, Schmeckpeper J, Gnecchi M, Dzau VJ: Paracrine mechanisms of stem cell reparative and regenerative actions in the heart. J Mol Cell Cardiol 2011;50:280-289.

-12 Mansergh FC, Wride MA, Rancourt DE: Neurons from stem cells: implications for understanding nervous system development and repair. Biochem Cell Biol 2000;78:613628.

$>13$ Bouwens L: Transdifferentiation versus stem cell hypothesis for the regeneration of islet beta-cells in the pancreas. Microsc Res Tech 1998;43:332-336.

14 Lodi D, Iannitti T, Palmieri B: Stem cells in clinical practice: applications and warnings. J Exp Clin Cancer Res 2011;30:9. a present-day challenge. Blood 1957;12:321323. marrow transplantation. Immunol Allergy Clin North Am 2010;30:1-15.

17 Le BK, Ringden O: Mesenchymal stem cells: properties and role in clinical bone marrow transplantation. Curr Opin Immunol 2006; 18:586-591

18 Chien KR: Regenerative medicine and human models of human disease. Nature 2008; 453:302-305.

19 Inoue H, Yamanaka S: The use of induced pluripotent stem cells in drug development. Clin Pharmacol Ther 2011;89:655-661.

20 Fahey MC, Wallace EM: Stem cells: research tools and clinical treatments. J Paediatr Child Health 2011;47:672-675.

21 McCormick JB, Huso HA: Stem cells and ethics: current issues. J Cardiovasc Transl Res 2010;3:122-127.

22 Xi J, Zhang SC: Stem cells in development of therapeutics for Parkinson's disease: a perspective. J Cell Biochem 2008;105:1153-1160.

23 Magga J, Savchenko E, Malm T, Rolova T, Pollari E, Valonen P, Lehtonen S, Jantunen E, Aarnio J, Lehenkari P, Koistinaho M, Muona A, Koistinaho J: Production of monocytic cells from bone marrow stem cells: therapeutic usage in Alzheimer's disease. J Cell Mol Med 2012;16:1060-1073.

24 Perin EC, Silva GV, Zheng Y, Gahremanpour A, Canales J, Patel D, Fernandes MR, Keller LH, Quan X, Coulter SA, Moore WH, Herlihy JP, Willerson JT: Randomized, double-blind pilot study of transendocardial injection of autologous aldehyde dehydrogenase-bright stem cells in patients with ischemic heart failure. Am Heart J 2012;163:415-421, 421.e1.

25 Cerletti M, Jurga S, Witczak CA, Hirshman MF, Shadrach JL, Goodyear LJ, Wagers AJ: Highly efficient, functional engraftment of skeletal muscle stem cells in dystrophic muscles. Cell 2008;134:37-47.
26 Tzouvelekis A, Koliakos G, Ntolios P, Baira I, Bouros E, Oikonomou A, Zissimopoulos A, Kolios G, Kakagia D, Paspaliaris V, Kotsianidis I, Froudarakis M, Bouros D: Stem cell therapy for idiopathic pulmonary fibrosis: a protocol proposal. J Transl Med 2011;9:182.

-27 Weiss DJ, Bertoncello I, Borok Z, Kim C, Panoskaltsis-Mortari A, Reynolds S, Rojas M, Stripp B, Warburton D, Prockop DJ: Stem cells and cell therapies in lung biology and lung diseases. Proc Am Thorac Soc 2011;8: 223-272.

-28 Rashid ST, Corbineau S, Hannan N, Marciniak SJ, Miranda E, Alexander G, HuangDoran I, Griffin J, Ahrlund-Richter L, Skepper J, Semple R, Weber A, Lomas DA, Vallier L: Modeling inherited metabolic disorders of the liver using human induced pluripotent stem cells. J Clin Invest 2010;120:3127-3136.

29 Smith A: A glossary for stem-cell biology. Nature 2006;441:1060.

30 Rossant J: Stem cells from the mammalian blastocyst. Stem Cells 2001;19:477-482.

31 De Miguel MP, Fuentes-Julian S, Alcaina Y: Pluripotent stem cells: origin, maintenance and induction. Stem Cell Rev 2010;6:633649.

32 Evans MJ, Kaufman MH: Establishment in culture of pluripotential cells from mouse embryos. Nature 1981;292:154-156.

33 Takahashi K, Yamanaka S: Induction of pluripotent stem cells from mouse embryonic and adult fibroblast cultures by defined factors. Cell 2006;126:663-676.

34 Ratajczak MZ, Zuba-Surma E, Kucia M, Poniewierska A, Suszynska M, Ratajczak J: Pluripotent and multipotent stem cells in adult tissues. Adv Med Sci 2012;57:1-17.

35 Augello A, Kurth TB, De BC: Mesenchymal stem cells: a perspective from in vitro cultures to in vivo migration and niches. Eur Cell Mater 2010;20:121-133. 
-36 Bruder SP, Jaiswal N, Haynesworth SE: Growth kinetics, self-renewal, and the osteogenic potential of purified human mesenchymal stem cells during extensive subcultivation and following cryopreservation. J Cell Biochem 1997;64:278-294.

37 Prockop DJ: Marrow stromal cells as stem cells for nonhematopoietic tissues. Science 1997;276:71-74.

- 38 Friedenstein AJ, Chailakhjan RK, Lalykina KS: The development of fibroblast colonies in monolayer cultures of guinea-pig bone marrow and spleen cells. Cell Tissue Kinet 1970;3:393-403.

-39 Barzilay R, Melamed E, Offen D: Introducing transcription factors to multipotent mesenchymal stem cells: making transdifferentiation possible. Stem Cells 2009;27:25092515.

-40 Jarvinen L, Badri L, Wettlaufer S, Ohtsuka T, Standiford TJ, Toews GB, Pinsky DJ, PetersGolden M, Lama VN: Lung resident mesenchymal stem cells isolated from human lung allografts inhibit $\mathrm{T}$ cell proliferation via a soluble mediator. J Immunol 2008;181:43894396.

-41 Majo F, Rochat A, Nicolas M, Jaoude GA, Barrandon Y: Oligopotent stem cells are distributed throughout the mammalian ocular surface. Nature 2008;456:250-254.

-42 Marone M, De RD, Bonanno G, Mozzetti S, Rutella S, Scambia G, Pierelli L: Cell cycle regulation in human hematopoietic stem cells: from isolation to activation. Leuk Lymphoma 2002;43:493-501.

-43 Kim CF, Jackson EL, Woolfenden AE, Lawrence S, Babar I, Vogel S, Crowley D, Bronson RT, Jacks T: Identification of bronchioalveolar stem cells in normal lung and lung cancer. Cell 2005;121:823-835.

44 Overturf K, al-Dhalimy M, Ou CN, Finegold M, Grompe M: Serial transplantation reveals the stem-cell-like regenerative potential of adult mouse hepatocytes. Am J Pathol 1997; 151:1273-1280.

$\checkmark 45$ de Rooij DG, Grootegoed JA: Spermatogonial stem cells. Curr Opin Cell Biol 1998;10: 694-701.

46 Bentzinger CF, Wang YX, von MJ, Rudnicki MA: The emerging biology of muscle stem cells: implications for cell-based therapies. Bioessays 2012, DOI: 10.1002/bies. 201200063.

-47 Beck B, Blanpain C: Mechanisms regulating epidermal stem cells. EMBO J 2012;31:20672075.

48 Ilic D, Polak JM: Stem cells in regenerative medicine: introduction. Br Med Bull 2011; 98:117-126.

-49 Bongso A, Richards M: History and perspective of stem cell research. Best Pract Res Clin Obstet Gynaecol 2004; 18:827-842.

50 Yao S, Chen S, Clark J, Hao E, Beattie GM, Hayek A, Ding S: Long-term self-renewal and directed differentiation of human embryonic stem cells in chemically defined conditions. Proc Natl Acad Sci USA 2006; 103:6907-6912.
Bongso A: Blastocyst culture for deriving human embryonic stem cells. Methods Mol Biol 2006;331:13-22.

52 Hambiliki F, Strom S, Zhang P, StavreusEvers A: Co-localization of NANOG and OCT4 in human pre-implantation embryos and in human embryonic stem cells. J Assist Reprod Genet 2012;29:1021-1028.

53 Wang Z, Oron E, Nelson B, Razis S, Ivanova $\mathrm{N}$ : Distinct lineage specification roles for NANOG, OCT4, and SOX2 in human embryonic stem cells. Cell Stem Cell 2012;10: 440-454.

54 Liang J, Wan M, Zhang Y, Gu P, Xin H, Jung SY, Qin J, Wong J, Cooney AJ, Liu D, Songyang Z: Nanog and Oct4 associate with unique transcriptional repression complexes in embryonic stem cells. Nat Cell Biol 2008; 10:731-739.

55 Baharvand $\mathrm{H}$, Ashtiani SK, Valojerdi MR, Shahverdi A, Taee A, Sabour D: Establishment and in vitro differentiation of a new embryonic stem cell line from human blastocyst. Differentiation 2004;72:224-229.

56 Doetschman TC, Eistetter H, Katz M, Schmidt W, Kemler R: The in vitro development of blastocyst-derived embryonic stem cell lines: formation of visceral yolk sac, blood islands and myocardium. J Embryol Exp Morphol 1985;87:27-45.

57 Hamazaki T, Iiboshi Y, Oka M, Papst PJ, Meacham AM, Zon LI, Terada N: Hepatic maturation in differentiating embryonic stem cells in vitro. FEBS Lett 2001;497:15-19.

58 Thoma EC, Maurus K, Wagner TU, Schartl M: Parallel differentiation of embryonic stem cells into different cell types by a single gene-based differentiation system. Cell Reprogram 2012;14:106-111.

-59 Shiroi A, Ueda S, Ouji Y, Saito K, Moriya K, Sugie Y, Fukui H, Ishizaka S, Yoshikawa M: Differentiation of embryonic stem cells into insulin-producing cells promoted by $\mathrm{Nkx} 2.2$ gene transfer. World J Gastroenterol 2005;11: 4161-4166.

60 Heydarkhan-Hagvall S, Gluck JM, Delman C, Jung M, Ehsani N, Full S, Shemin RJ: The effect of vitronectin on the differentiation of embryonic stem cells in a 3D culture system. Biomaterials 2012;33:2032-2040.

61 Moodley Y, Ilancheran S, Samuel C, Vaghjiani V, Atienza D, Williams ED, Jenkin G, Wallace E, Trounson A, Manuelpillai U: Human amnion epithelial cell transplantation abrogates lung fibrosis and augments repair. Am J Respir Crit Care Med 2010;182:643651.

62 Ilancheran S, Moodley Y, Manuelpillai U: Human fetal membranes: a source of stem cells for tissue regeneration and repair? Placenta 2009;30:2-10.

63 Korbling M, Estrov Z: Adult stem cells for tissue repair - a new therapeutic concept? $\mathrm{N}$ Engl J Med 2003;349:570-582.

64 Chimutengwende-Gordon M, Khan WS: Advances in the use of stem cells and tissue engineering applications in bone repair. Curr Stem Cell Res Ther 2012;7:122-126.
65 Obradovic S, Rusovic S, Balint B, Ristic-Andelkov A, Romanovic R, Baskot B, Vojvodic D, Gligic B: Autologous bone marrow-derived progenitor cell transplantation for myocardial regeneration after acute infarction. Vojnosanit Pregl 2004;61:519-529.

66 Menasche P, Alfieri O, Janssens S, McKenna W, Reichenspurner H, Trinquart L, Vilquin JT, Marolleau JP, Seymour B, Larghero J, Lake S, Chatellier G, Solomon S, Desnos M, Hagege AA: The Myoblast Autologous Grafting in Ischemic Cardiomyopathy (MAGIC) trial: first randomized placebocontrolled study of myoblast transplantation. Circulation 2008;117:1189-1200.

67 Meirelles LS, Nardi NB: Methodology, biology and clinical applications of mesenchymal stem cells. Front Biosci 2009;14:42814298.

68 Yeung TY, Seeberger KL, Kin T, Adesida A, Jomha N, Shapiro AM, Korbutt GS: Human mesenchymal stem cells protect human islets from pro-inflammatory cytokines. PLoS One 2012;7:e38189.

69 Passier R, Mummery C: Origin and use of embryonic and adult stem cells in differentiation and tissue repair. Cardiovasc Res 2003;58:324-335.

70 Smart N, Riley PR: The stem cell movement. Circ Res 2008;102:1155-1168.

71 Voog J, Jones DL: Stem cells and the niche: a dynamic duo. Cell Stem Cell 2010;6:103-115.

72 Kiefer JC: Primer and interviews: the dynamic stem cell niche. Dev Dyn 2011;240: 737-743.

73 Yeung TM, Chia LA, Kosinski CM, Kuo CJ: Regulation of self-renewal and differentiation by the intestinal stem cell niche. Cell Mol Life Sci 2011;68:2513-2523.

74 Wagers AJ: The stem cell niche in regenerative medicine. Cell Stem Cell 2012;10:362369.

75 He XC, Zhang J, Tong WG, Tawfik O, Ross J, Scoville DH, Tian Q, Zeng X, He X, Wiedemann LM, Mishina Y, Li L: BMP signaling inhibits intestinal stem cell self-renewal through suppression of Wnt-beta-catenin signaling. Nat Genet 2004;36:1117-1121.

-76 Kulkarni V, Khadilkar RJ, Magadi SS, Inamdar MS: Asrij maintains the stem cell niche and controls differentiation during Drosophila lymph gland hematopoiesis. PLoS One 2011;6:e27667.

77 Snippert HJ, Clevers H: Tracking adult stem cells. EMBO Rep 2011;12:113-122.

78 Daniela F, Vescovi AL, Bottai D: The stem cells as a potential treatment for neurodegeneration. Methods Mol Biol 2007;399:199_ 213.

79 Jessell TM, Melton DA: Diffusible factors in vertebrate embryonic induction. Cell 1992; 68:257-270.

- 80 Tsai RY, McKay RD: Cell contact regulates fate choice by cortical stem cells. J Neurosci 2000;20:3725-3735.

81 Young TH, Hung CH: Behavior of embryonic rat cerebral cortical stem cells on the PVA and EVAL substrates. Biomaterials 2005;26: 4291-4299. 
82 Ruoslahti E: Stretching is good for a cell. Sci- 100 Woltjen K, Michael IP, Mohseni P, Desai R, ence 1997;276:1345-1346.

$\$ 83$ Streuli C: Extracellular matrix remodelling and cellular differentiation. Curr Opin Cell Biol 1999;11:634-640.

84 Knoblich JA: Asymmetric cell division during animal development. Nat Rev Mol Cell Biol 2001;2:11-20.

85 Morrison SJ, Kimble J: Asymmetric and symmetric stem-cell divisions in development and cancer. Nature 2006;441:10681074.

86 Yamashita YM: Cell adhesion in regulation of asymmetric stem cell division. Curr Opin Cell Biol 2010;22:605-610.

$\$ 87$ Neumuller RA, Knoblich JA: Dividing cellular asymmetry: asymmetric cell division and its implications for stem cells and cancer. Genes Dev 2009;23:2675-2699.

88 Horvitz HR, Herskowitz I: Mechanisms of asymmetric cell division: two Bs or not two Bs, that is the question. Cell 1992;68:237-255.

-89 Knoblich JA: Mechanisms of asymmetric stem cell division. Cell 2008;132:583-597.

-90 Rossant J: Stem cells and early lineage development. Cell 2008;132:527-531.

91 Takahashi K, Tanabe K, Ohnuki M, Narita M, Ichisaka T, Tomoda K, Yamanaka S: Induction of pluripotent stem cells from adult human fibroblasts by defined factors. Cell 2007;131:861-872.

$\checkmark 92$ Wernig M, Meissner A, Foreman R, Brambrink $\mathrm{T}, \mathrm{Ku} \mathrm{M}$, Hochedlinger $\mathrm{K}$, Bernstein $\mathrm{BE}$, Jaenisch R: In vitro reprogramming of fibroblasts into a pluripotent ES-cell-like state. Nature 2007;448:318-324.

-93 Ebben JD, Zorniak M, Clark PA, Kuo JS: Introduction to induced pluripotent stem cells: advancing the potential for personalized medicine. World Neurosurg 2011;76:270-275.

$\$ 4$ Pietronave S, Prat M: Advances and applications of induced pluripotent stem cells. Can J Physiol Pharmacol 2012;90:317-325.

\$95 Kim JB, Zaehres H, Wu G, Gentile L, Ko K, Sebastiano V, Arauzo-Bravo MJ, Ruau D, Han DW, Zenke M, Scholer HR: Pluripotent stem cells induced from adult neural stem cells by reprogramming with two factors. Nature 2008;454:646-650.

$\$ 96$ Kim JB, Sebastiano V, Wu G, Arauzo-Bravo MJ, Sasse P, Gentile L, Ko K, Ruau D, Ehrich $\mathrm{M}$, van den Boom D, Meyer J, Hubner K, Bernemann C, Ortmeier C, Zenke M, Fleischmann BK, Zaehres H, Scholer HR: Oct4-induced pluripotency in adult neural stem cells. Cell 2009;136:411-419.

\$97 Stadtfeld M, Nagaya M, Utikal J, Weir G, Hochedlinger K: Induced pluripotent stem cells generated without viral integration. Science 2008;322:945-949.

98 Okita K, Nakagawa M, Hyenjong H, Ichisaka T, Yamanaka S: Generation of mouse induced pluripotent stem cells without viral vectors. Science 2008;322:949-953.

$\checkmark 99$ Kaji K, Norrby K, Paca A, Mileikovsky M, Mohseni P, Woltjen K: Virus-free induction of pluripotency and subsequent excision of reprogramming factors. Nature 2009;458: 771-775. Mileikovsky M, Hamalainen R, Cowling R, Wang W, Liu P, Gertsenstein M, Kaji K, Sung HK, Nagy A: piggyBac transposition reprograms fibroblasts to induced pluripotent stem cells. Nature 2009;458:766-770.

101 Daley GQ: Stem cells: roadmap to the clinic. J Clin Invest 2010;120:8-10.

102 Kroon E, Martinson LA, Kadoya K, Bang AG, Kelly OG, Eliazer S, Young H, Richardson M, Smart NG, Cunningham J, Agulnick $\mathrm{AD}$, D’Amour KA, Carpenter MK, Baetge EE: Pancreatic endoderm derived from human embryonic stem cells generates glucose-responsive insulin-secreting cells in vivo. Nat Biotechnol 2008;26:443-452.

103 Trivedi HL, Vanikar AV, Thakker U, Firoze A, Dave SD, Patel CN, Patel JV, Bhargava $A B$, Shankar V: Human adipose tissue-derived mesenchymal stem cells combined with hematopoietic stem cell transplantation synthesize insulin. Transplant Proc 2008;40:1135-1139.

104 Gratwohl A, Heim D: Current role of stem cell transplantation in chronic myeloid leukaemia. Best Pract Res Clin Haematol 2009; 22:431-443.

105 Hackanson B, Waller CF: Long-term follow-up of patients with chronic myeloid leukemia having received autologous stem cell transplantation. Ann Hematol 2011;90: 395-399.

106 Kuo TK, Hung SP, Chuang CH, Chen CT, Shih YR, Fang SC, Yang VW, Lee OK: Stem cell therapy for liver disease: parameters governing the success of using bone marrow mesenchymal stem cells. Gastroenterology 2008;134:2111-2121, 2121.e1-3.

107 Pai M, Zacharoulis D, Milicevic MN, Helmy S, Jiao LR, Levicar N, Tait P, Scott M, Marley SB, Jestice K, Glibetic M, Bansi D, Khan SA, Kyriakou D, Rountas C, Thillainayagam A, Nicholls JP, Jensen S, Apperley JF, Gordon MY, Habib NA: Autologous infusion of expanded mobilized adult bone marrow-derived CD34+ cells into patients with alcoholic liver cirrhosis. Am J Gastroenterol 2008;103:1952-1958.

108 Tzouvelekis A, Antoniadis A, Bouros D: Stem cell therapy in pulmonary fibrosis. Curr Opin Pulm Med 2011;17:368-373.

109 Banerjee ER, Laflamme MA, Papayannopoulou T, Kahn M, Murry CE, Henderson WR Jr: Human embryonic stem cells differentiated to lung lineage-specific cells ameliorate pulmonary fibrosis in a xenograft transplant mouse model. PLoS One 2012;7:e33165.

- 110 Cassinotti A, Annaloro C, Ardizzone S, Onida F, Della VA, Clerici M, Usardi P, Greco S, Maconi G, Porro GB, Deliliers GL: Autologous haematopoietic stem cell transplantation without CD34+ cell selection in refractory Crohn's disease. Gut 2008;57: 211-217.

111 Oyama Y, Craig RM, Traynor AE, Quigley K, Statkute L, Halverson A, Brush M, Verda L, Kowalska B, Krosnjar N, Kletzel M, Whitington PF, Burt RK: Autologous hemato- poietic stem cell transplantation in patients with refractory Crohn's disease. Gastroenterology 2005; 128:552-563.

112 Hagege AA, Marolleau JP, Vilquin JT, Alheritiere A, Peyrard S, Duboc D, Abergel E, Messas E, Mousseaux E, Schwartz K, Desnos M, Menasche P: Skeletal myoblast transplantation in ischemic heart failure: long-term follow-up of the first phase I cohort of patients. Circulation 2006;114:I108I113.

113 Burt RK, Loh Y, Cohen B, Stefoski D, Balabanov R, Katsamakis G, Oyama Y, Russell EJ, Stern J, Muraro P, Rose J, Testori A, Bucha J, Jovanovic B, Milanetti F, Storek J, Voltarelli JC, Burns WH: Autologous nonmyeloablative haemopoietic stem cell transplantation in relapsing-remitting multiple sclerosis: a phase I/II study. Lancet Neurol 2009;8:244-253.

114 Bjorklund LM, Sanchez-Pernaute R, Chung $\mathrm{S}$, Andersson T, Chen IY, McNaught KS, Brownell AL, Jenkins BG, Wahlestedt C, Kim KS, Isacson O: Embryonic stem cells develop into functional dopaminergic neurons after transplantation in a Parkinson rat model. Proc Natl Acad Sci USA 2002;99: 2344-2349.

115 Mackay-Sim A, Feron F, Cochrane J, Bassingthwaighte L, Bayliss C, Davies W, Fronek P, Gray C, Kerr G, Licina P, Nowitzke A, Perry C, Silburn PA, Urquhart S, Geraghty T: Autologous olfactory ensheathing cell transplantation in human paraplegia: a 3-year clinical trial. Brain 2008;131:2376-2386.

-116 Lindvall O, Kokaia Z: Stem cells for the treatment of neurological disorders. Nature 2006;441:1094-1096.

117 Rabinovich SS, Seledtsov VI, Banul NV, Poveshchenko OV, Senyukov VV, Astrakov SV, Samarin DM, Taraban VY: Cell therapy of brain stroke. Bull Exp Biol Med 2005; 139:126-128.

118 Le BK, Frassoni F, Ball L, Locatelli F, Roelofs H, Lewis I, Lanino E, Sundberg B, Bernardo ME, Remberger M, Dini G, Egeler RM, Bacigalupo A, Fibbe W, Ringden O: Mesenchymal stem cells for treatment of steroid-resistant, severe, acute graft-versus-host disease: a phase II study. Lancet 2008;371:1579-1586.

119 Nasef A, Ashammakhi N, Fouillard L: Immunomodulatory effect of mesenchymal stromal cells: possible mechanisms. Regen Med 2008;3:531-546.

120 Filip S, Mokry J, Horacek J, English D: Stem cells and the phenomena of plasticity and diversity: a limiting property of carcinogenesis. Stem Cells Dev 2008;17:1031-1038.

121 Cunningham JJ, Ulbright TM, Pera MF, Looijenga LH: Lessons from human teratomas to guide development of safe stem cell therapies. Nat Biotechnol 2012;30:849-857.

122 Zarzeczny A, Caulfield T: Emerging ethi$\mathrm{cal}$, legal and social issues associated with stem cell research and the current role of the moral status of the embryo. Stem Cell Rev 2009;5:96-101. 